AperTO - Archivio Istituzionale Open Access dell'Università di Torino

\title{
A grey future for Europe: Sciurus carolinensis is replacing native red squirrels in Italy
}

\section{This is the author's manuscript}

Original Citation:

\section{Availability:}

This version is available http://hdl.handle.net/2318/1615660

since 2017-01-17T14:33:49Z

Published version:

DOI:10.1007/s10530-013-0502-3

Terms of use:

Open Access

Anyone can freely access the full text of works made available as "Open Access". Works made available under a Creative Commons license can be used according to the terms and conditions of said license. Use of all other works requires consent of the right holder (author or publisher) if not exempted from copyright protection by the applicable law. 
This is the author's final version of the contribution published as:

Bertolino, Sandro; Cordero di Montezemolo, Nicola; Preatoni, Damiano G.; Wauters, Lucas A; Martinoli, Adriano. A grey future for Europe: Sciurus carolinensis is replacing native red squirrels in Italy. BIOLOGICAL INVASIONS. 16 (1) pp: 53-62.

DOI: $10.1007 / \mathrm{s} 10530-013-0502-3$

The publisher's version is available at:

http://link.springer.com/content/pdf/10.1007/s10530-013-0502-3

When citing, please refer to the published version.

Link to this full text:

http://hdl.handle.net/2318/1615660 


\title{
A grey future for Europe: Sciurus carolinensis is replacing native red squirrels in Italy
}

Sandro Bertolino $^{1 *}$, Nicola Cordero di Montezemolo ${ }^{1}$, Damiano G. Preatoni ${ }^{2}$, Lucas A. Wauters ${ }^{2}$ and Adriano Martinoli ${ }^{2}$

${ }^{1}$ Department of Agriculture, Forest and Food Sciences, University of Turin, Via L. da Vinci 44, 10095 Grugliasco (TO), Italy

${ }^{2}$ Environment Analysis and Management Unit - Guido Tosi Research Group, Department of Theoretical and Applied Sciences, University of Insubria, Varese.

\begin{abstract}
Introduced mammals can cause extinction of native species due to replacement competition, disease, predation or hybridization. We studied the colonization of Piedmont (NW-Italy) by American grey squirrel (Sciurus carolinensis) and its effect on the native red squirrel (Sciurus vulgaris). Presence/absence data ( $2 \times 2 \mathrm{~km}$ squares), of both species were (re)constructed using questionnaires, literature, existing databases, unpublished information, and direct monitoring with hair-tubes.

In 1970 red squirrels were still widespread and greys were restricted to forests near the introduction site. By 1990, grey squirrels had increased their range to $220 \mathrm{~km}^{2}$, which coincided with the disappearance of native squirrels from 33 squares inside this range. The invasive species continued its spread occupying an area of $2,016 \mathrm{~km}^{2}$ in 2010 ; within this area red squirrels went extinct in 88 squares. Overall, from 1970 to 2010 red squirrel went extinct in $62 \%$ of $2 \times 2 \mathrm{~km}$ squares (ca. 1,689 $\mathrm{km}^{2}$ ), and were replaced by grey squirrels. The spread of the alien species was slow in the first twenty years, but doubled in the successive two decades. Nevertheless spread was slower than in Ireland and England. Grey squirrel adapt to climate and habitats in both North and South Europe, causing extinction of the native red squirrel. A EU LIFE co-funded project with the aim to control the grey squirrel in North Italy and recent trade-restrictions and trade-ban are a first step in reducing the risk of grey squirrels invading other countries, but their effectiveness will have to be evaluated.
\end{abstract}

Keywords: Sciurus carolinensis; Sciurus vulgaris; Extinction; Interspecific competition; Invasive alien species; Species Range

\section{Introduction}

The introduction of non-native species is changing ecosystems functioning, altering materials and energy flows (Ehrenfeld 2010; Strayer 2012). One of the changes commonly reported is the extinction of native species due to different ecological processes, including competition, disease, predation and hybridization (Clavero et al. 2009; Vié et al. 2009; Collen et al. 2012). The theory of limiting similarity predicts that interspecific competition should lead to a reduction in the niche overlap of competing species (MacArthur and Levins 1967). The introduction of non-native species may interfere with this process and the niche of the native and the introduced species might overlap 
considerably, thus causing detrimental effects that may lead to extinction of the native species. Competitive interactions between introduced and native species have been shown in several studies (e.g. Cadi \& Joly 2003; Gurnell et al. 2004; Glen and Dickman 2008).

Not all introduced species adapt to new habitats, and not all of these species spread and become invasive (Williamson 1996, Jeschke and Strayer 2005; Ferreira et al. 2012). Several authors have reviewed correlates of invasion success looking for predictors of establishment success (e.g. Kolar and Lodge 2001; Hayes and Barry 2008), however we are still far from describing general rules useful in risk assessment procedures. Nevertheless, the invasiveness of a species in previous areas of introductions should be an indication of its potential adaptability to other parts of the world (Wittenberg and Cock 2001). Furthermore, a species can be harmful in an area and spread apparently without any impact in another one. Among mammals, introduced tree squirrels can establish self-sustaining populations from only few founders, are likely to become invasive and cause problems to native wildlife and/or damage agricultural crops, natural woods and tree plantations (e.g. Gurnell and Pepper 1993; Wauters et al. 2005; Bertolino 2008, 2009; Bertolino and Lurz 2013).

A well known case of competitive exclusion of a native species by an introduced one is the replacement of the Eurasian red squirrel (Sciurus vulgaris) by the Eastern grey squirrel (Sciurus carolinensis) in Great Britain and Ireland (Gurnell and Pepper 1993; Lawton et al. 2010). The grey squirrel is a North American species that has been introduced to many localities of North America, Australia, South Africa, Great Britain, Ireland and Italy (Bertolino 2009). In Europe, the grey squirrel was introduced to Great Britain on more than 30 occasions from 1876 until 1929 (Middleton 1932; Gurnell and Pepper 1993) and to Ireland in 1913 (O'Teangana et al. 2000). At least 20 separate introductions took place in Italy (Bertolino 2008; Martinoli et al. 2010). Presently, the range of introduced grey squirrel populations covers most of England and Wales, part of Scotland, the eastern part of Ireland, as well as many areas in Northwestern Italy and a location in central Italy (Wauters et al. 1997a; O’Teangana et al. 2000; Bertolino 2008; Gurnell et al. 2008; Martinoli et al. 2010).

The spread of the grey squirrel in Great Britain and Ireland has been associated with a dramatic decline of the native red squirrel. This replacement is caused by competition for food resources between the two species that reduces juvenile body growth and recruitment, and female breeding success in red squirrel (Wauters et al. 2002a, b; Gurnell et al. 2004). The replacement is also disease-mediated, as grey squirrels act as a reservoir host to a squirrel poxvirus that causes high mortality in red squirrels (Sainsbury et al. 2000; Tompkins et al. 2002; Rushton et al. 2006). Recently, screening of macro-parasites in Italy is investigating whether other parasite-mediated competition mechanisms might be involved (Romeo et al. In prep).

The grey squirrel is spreading and impacting biodiversity and commercial forestry in Great Britain, where it is a serious pest for its impact on trees through bark stripping (Mayle et al. 2003; Gurnell et al. 2008). In Italy, damage in plantations or to crops is still limited (Signorile and Evans 2007). However, not everywhere has the species proven to be invasive. In South Africa the grey squirrel has been introduced to the Cape Peninsula more than a century ago. Here, after an initial spread the species remained confined to agricultural and afforested environments, not being able to invade native ecosystems (Long 2003). In Australia the species thrived for some decades in two areas in Melbourne and then became extinct (Long 2003), while it was eradicated from another (Peacock 2009).

Until now, spatially explicit population dynamics models have been used to forecast the future spread of the grey squirrel within Italy and in neighbouring countries and the risk that it poses to the red squirrel (Lurz et al. 2001; Tattoni et al. 2005, 2006; Bertolino et al. 2008). However, published information on the spatial spread of the grey squirrel and the effect on the red squirrel is still limited (Wauters et al. 1997b). 
Here we use a database on red and grey squirrel presence in Piedmont, the region were the first introduction of the American species in Italy took place, to show the spread of the introduced species and the impact on the native one. We investigated whether the grey squirrel is replacing the red squirrel in the area of spread. We also tested the hypothesis that the grey squirrel adapted to Italian habitats, comparing the spread rate of the species in this country in respect to the rates recorded in England and Ireland (Okubo et al. 1986; O'Teangana et al. 2000). If the replacement of the red squirrel by the American species is confirmed in Italy, the future diffusion of the grey squirrel beyond the Italian border represents a serious threat for the survival of the native species in the long-term at an European scale.

\section{Materials and methods}

The study was carried out in Piedmont, a region in northwestern Italy (Fig. 1). Piedmont can be divided into four main geographical areas: the Alps (with peaks above 1,500 m a.s.1.), the pre-Alps (with peaks below 1,500 m a.s.1.), inland low-hills and Apennines (the hills bordering the River Po, Monferrato, Langhe, and Apennines uplands), and lowlands (including wide Alpine valley floors below $600 \mathrm{~m}$ a.s.1.). The region covers $25,383 \mathrm{~km}^{2}$, with $29 \%$ of lowlands and $71 \%$ of mountains and hills (Gottero et al. 2007). Most of the plain and hilly area is covered by agricultural lands (37\%) and grasslands (pastures and meadows, 13\%). Woodlands are mainly spread across the hilly areas, Alps, and Apennines, and extremely reduced in lowlands; overall, forest cover is $34 \%$.

Data on the presence of the grey squirrel in Piedmont are available from 1970s. A map of the red squirrel distribution in Piedmont in the 1970s was prepared collecting data from the literature, existing databases and unpublished information. The map is based on a large dataset of 1,089 records and uses a grid with $2 \times 2 \mathrm{~km}$ squares. However the species was probably even more widely distributed considering the nearly continuous forest cover in the Alps, the Apennines and in most hilly areas. Therefore the probable red squirrel distribution in the area colonised by the grey squirrel was evaluated considering the confirmed records and the suitability of other areas. A single square was considered suitable when a woodland $>10$ ha was present inside the square (Fig. 1 right); the probability of red squirrel occupancy of forests larger than 10 ha in fragmented landscapes is higher than 90\% (Rodrìguez and Andrén 1999). The successive analyses were carried out using only the confirmed records.

Presence or absence of both squirrel species in 1970 in the grey squirrel range was established through questionnaires to gamekeepers, hunters, farmers, park-owners and foresters (Wauters et al. 1997a, b). The distribution of red and grey squirrels from 1990 onwards was reconstructed using presence/absence data from both species continuously collected by researchers at the University of Turin. In 1998-1999, 2007 and 2010 surveys with hair-tubes were conducted to determine the distribution of both species in a standardised way (Gurnell et al. 2004; Bertolino et al. 2009). Data were georeferenced in a GIS-based database and were used to evaluate the overall range expansion of the introduced species and the red squirrel extinction.

Effects of competition were evaluated assessing the presence/absence of the two species in a $2 \mathrm{x}$ $2 \mathrm{~km}$-square grid. It was assumed that grey squirrels were present in a grid square from the year they were first recorded, regardless of a possible extinction and successive recolonization of woodlands. Red squirrels were deleted from squares when they were not reported in the period between two successive surveys.

The speed of grey squirrel colonisation was calculated with the method used by Okubo et al. (1989) for England and by Ò'Teangana et al. (2000) for Ireland in order to compare the values between different European countries. Utilizing the data of the four periods described above, the rate of spread was calculated measuring the shortest distance from the centre of the previously occupied squares to the centre of those newly occupied in all directions. These measurements were 
then divided by the number of years between the respective surveys to obtain the minimum speed of colonisation $\left(\mathrm{V}_{\min }\right)$ in $\mathrm{km} / \mathrm{year}$. The two-dimensional diffusion coefficient (D) was estimated from the equation in Okubo et al. (1989):

$\mathrm{V}_{\min }=2(\mathrm{AD})^{1 / 2}$

Where $\mathrm{A}$ is the intrinsic rate of natural increase of grey squirrel distribution, which has been estimated by Okubo et al. (1989) at $0.82 \mathrm{~km} /$ year.

To test the possible effects of forest fragmentation on the persistence of red squirrels, we measured the area of the woodlands inside the grey squirrel range where native squirrels disappeared, and, for patches $<10$ ha, the distance from woodland patches with an area greater than $10 \mathrm{ha}$. These measures are known to influence the persistence of the red squirrel in fragmented habitats with small forest patches (Celada et al. 1994; Rodríguez and Andrén 1999; Verbeylen et al. 2003).

We used $1: 10,000$ digitised maps of land cover (edited by Regione Piemonte and Istituto per le Piante da Legno e l'Ambiente) imported to QGIS software to measure the size and distance of forest patches with red and grey squirrels' presence. We then explored whether the habitat was more fragmented in the early area of grey squirrel distribution (1970-1990 range) than in the area colonised after 1990 (1990-2010 range).A non-parametric procedure (Mann-Whitney U-tests) was used to evaluate differences in patch size between these periods. The distribution of interpatch distances was highly skewed and data were log-transformed to meet assumptions of normality (Shapiro-Wilk's test on log-transformed data, $\mathrm{W}=0.96$ ). As for patch size, we compared interparch distances between the two periods using a two-way ANOVA with period, patch size class (small patches $>1$ ha, larger patches $>10 \mathrm{ha}$ ) and the interaction as factors. Means are reported $\pm \mathrm{SE}$.

\section{Results}

The reconstructed distribution of the red squirrel in the area of the grey squirrel invasion in Piedmont before 1970 (considering both squares where the species was recorded, dark red, and those suitable for the species but not investigated, light red, Fig. 1) shows that the native species was widely distributed. In 1970 grey squirrels were still restricted to the Stupinigi forests, the site of first introduction, where both species coexisted (Fig. 2). The last observation of a red squirrel at Stupinigi occurred in the 1979-80 winter (Wauters et al. 1997b). By 1990, grey squirrels had drastically increased their range to $220 \mathrm{~km}^{2}$. Concomitantly, in this area red squirrels disappeared from $332 \times 2 \mathrm{~km}$-squares where they were previously recorded (Fig. 3). By 2000 the range of the invasive species had increased to $881 \mathrm{~km}^{2}$ and red squirrels went extinct from an additional 30 squares. In 2010 the grey squirrel range reached an area of $2,016 \mathrm{~km}^{2}$ between the cities of Turin and Cuneo. During these 10 years, the red squirrel disappeared in another 58 squares. Hence, from 1970 to 2010 the red squirrel went extinct in 120 out of 194 (61.9\%) 2x2 km squares, being replaced by the grey squirrel (Fig. 3). Overall, the red squirrel is no longer present in an area of $1,689 \mathrm{~km}^{2}$ that was previously occupied by the species.

Among 153 woodland patches inside the grey squirrel range where red squirrels were present in 1970 and went extinct after the arrival of the introduced species, $20(13.1 \%)$ were $>10$ ha, the other 133 were within $2 \mathrm{~km}(\mathrm{n}=113,73.8 \%)$ or $3.6 \mathrm{~km}(\mathrm{n}=20,13.1 \%)$ from a woodland patch $>10$ ha (Fig. 4). We do not have indications of any woodlot in which red squirrels have gone extinct in the absence of grey squirrel.

Between 1970 and 2010 the grey squirrel area of occupancy increased with a pattern corresponding to the first part of a logistic curve (Fig. $5, R^{2}=0.96, F_{1,2}=53.8, P=0.018$ ). In the same period, the area of occupancy of the red squirrel decreased linearly $\left(R^{2}=0.91, F_{1,2}=19.4, P\right.$ 
$=0.048)$. The linear spread of the colonization by the alien species was low in the first twenty years of our survey (Table 1, 1970-1990: $0.33 \mathrm{~km} /$ year) and doubled in the successive two decades (19902010: 0.56-0.65 km/year). Accordingly, the two-dimensional diffusion coefficient increase from $0.03 \mathrm{~km}^{2} /$ year (1970-1990) to 0.10-0.13 (1990-2010). The mean dimension of the forest patches in the area of grey squirrel spread from 1990 to 2010 (Fig. 6, $n=2425$, mean area 13.08 \pm 1.20 ha) was greater than patches present in the 1970-1990 area $(\mathrm{n}=255,3.10 \pm 0.31$ ha; Mann-Whitney U-test, $P$ $<0.001)$. Interpatch distance differed between periods $\left(F_{1,4038}=21.4, P<0.0001\right)$ but the period effect was only significant for the smaller patches (interaction period $*$ patch size class $F_{1,4038}=$ 6.87, $P=0.009$; Tukey test on differences between periods: for patches $>1$ ha $P=0.001$; for patches $>10$ ha $P=0.47$ ). Distance between smaller patches was slightly larger in 1990-2010 than in the 1970-1990 range, while for the larger patches (> $10 \mathrm{ha}$ ) there was an opposite, but non significant trend.

\section{Discussion}

The grey squirrel successfully colonised Italian habitats: from a single documented introduction in a woodland near Turin in 1948 (Bertolino and Genovesi 2005), a large (meta)-population occupied a range of more than $2000 \mathrm{~km}^{2}$ between the cities of Turin and Cuneo in 2010. The spread of the invasive species followed a pattern corresponding to the first part of a logistic curve, with a slow spread in the first forty years and a rapid increase in the last twenty years. In the same period, the red squirrel went extinct in most of the forested areas occupied by the introduced species. The increase of the extinction area followed a linear pattern and in 2010 the native species was still present in only $38 \%$ of previously occupied $2 \times 2 \mathrm{~km}$ squares inside the grey squirrel range.

The grey squirrel spread rate was lower than in Ireland and East Anglia, England (Table 1). This difference could be due to the interaction of genetic and environmental factors. Founder size was only 4 individuals in Piedmont (Bertolino and Genovesi 2005), 12 in Ireland (O'Teangana et al. 2000), while there have been multiple introductions in East Anglia (Reynolds 1985). Signorile and colleagues (unpublished data) analysing animals from these three areas demonstrate a positive relationship between founder size, local genetic diversity and individual squirrel dispersal propensity, with lower values recorded in Piedmont.

The low dispersal propensity of the grey squirrels may have been influenced also by the very low forest cover in Piedmont. According to our results, a stepping-stone mechanism could be proposed to explain the dispersal process. Grey squirrel presence in highly fragmented landscapes is influenced by woodland size, quality and isolation (Fitzgibbon 1993; Wauters et al. 1997a). For instance, in Piedmont the mean distance between woodlands in the area colonised by the grey squirrel in the 1990s was about $1 \mathrm{~km}$ (Wauters et al. 1997a). This distance is well over the perceptual range - i.e. the maximum distance from which an animal can perceive the presence of remote landscape elements such as a forest patch - which is between $300-400 \mathrm{~m}$ for grey squirrels (Zollner 2000). The landscape in the Po Plain where grey squirrels are spreading is characterized by few high-quality broadleaf or mixed woodlands dispersed in a matrix of open habitats. This could result in a scenario where grey squirrels show low dispersal propensity with animals emigrating from good woodlands only when forced by saturation. The spread rate increased after 1990 when the grey squirrel entered an area with larger forest patches and more patches of $>10$ ha. Interpatch distances of larger patches (> $10 \mathrm{ha}$ ) were not significantly smaller in the range after 1990 than in that occupied before 1990. The species is now spreading in the hilly system of the Piedmont region and is approaching the Alpine valleys where the forest cover is often continuous. Therefore, we can expect a further increase in the spread rate in a near future if no population control is undertaken. 
The spread of the grey squirrel clearly coincided with the extinction of the red squirrel in most of the wooded areas colonized by the alien species. Considering the occupancy area, the grey squirrel spread followed a pattern that could be described by the first part of a logistic curve, characterized by a lag-phase when the spread was very low and a successive phase of rapid increase. The presence of a lag-phase is common in the colonization process of introduced species and may be due to the Allee effect, landscape heterogeneity, low connectivity or simply to stochastic events (Crooks 2005; Bertolino 2009; Marsico et al. 2010). In the same period, the area of occupancy of the red squirrel decreased linearly. Between 1970 and 2010, the native species went extinct in $62 \%$ of previously occupied squares included in the 2010 grey squirrel range.

Red squirrel presence in fragmented landscapes may be negatively influenced by the increase in forest fragmentation or by a source-sink dynamics with the disappearance from the smaller and isolated patches (Celada et al. 1994; Verbeylen et al. 2003). However, red squirrels have a high probability ( $>90 \%$ ) to persist in forest patches $>10$ ha (Rodríguez and Andrén 1999), and both sexes can easily disperse between forest fragments, with dispersal distances of up to $4.1 \mathrm{~km}$ (Wauters et al. 2010, 2011). For example, in an earlier study in the Po Plain red squirrel persistence in smaller woodlots decreases with the distance from source areas (woods $>10$ ha) and was $80 \%$ at $2 \mathrm{~km}$ and $60 \%$ at $3.5 \mathrm{~km}$ (Celada et al. 1994). In the grey squirrel range in Piedmont, red squirrels not only went extinct in small, more isolated woodlands (within $3.6 \mathrm{~km}$ from source areas), but also disappeared from larger forests (> 100 ha, e.g. Stupinigi; Racconigi) where the species should persist, even in heavily fragmented landscapes. Moreover, woodland cover in the study area did not decrease between 1970 and 2010, except from some harvest of poplar (Populus canadensis) plantations. Finally, in other areas in northern Italy with fragmented woodlands, and without grey squirrels, the red squirrel range is increasing rather than decreasing (Bon et al. 2008). Therefore, forest fragmentation can not explain the extinction of the red squirrel from such a large area.

Considering the dynamic of the grey squirrel colonization of these woodland areas and the extinction of the native species some years later, the only explanation is the replacement of one species by the other, as already reported for Great Britain and Ireland (Gurnell and Pepper 1993; O'Teangana et al. 2000). This conclusion is further supported by detailed population monitoring of both species in some study sites where they initially co-occurred and red squirrels went extinct in only 5 to 10 years due to competition for food resources (Wauters et al. 2002a, b; Gurnell et al. 2004; Bertolino and Wauters, unpubl. Data).

\section{Conclusion}

Our results show that the grey squirrel adapted to habitats in northern Italy and is able to spread in a highly fragmented landscape. Having reached the hills and approaching the Alps where large forests are present, we expect a higher dispersal rate in the future. The Piedmont population is only one of the many populations that are already present in Italy. In Lombardy, in particular, in the last decades more than 26 nuclei of grey squirrel have been recorded (Martinoli et al. 2010; Authors unpublished data). These multiple introductions increase the risks posed by the alien species. The probable high genetic variability of different populations and the presence of animals in areas with large forests may result in a spread even faster than predicted from recent spatially explicit population dynamics modelling (Lurz et al. 2001; Tattoni et al. 2005, 2006; Bertolino et al. 2008). Unfortunately, also in Italy the spread of the grey squirrel coincides with the local extinction of the red squirrel. Hence, grey squirrel easily adapts to climate and habitats of North and South Europe and replaces the native squirrel species. The diffusion of the grey squirrel beyond the Italian border or the introduction of the American species in other countries would represent a serious threat for the survival of the red squirrel in the long-term at a European scale. The starting of a LIFE funded project with the aim to control or eradicate the grey squirrel in North Italy (www.rossoscoiattolo.eu) and the recent trade ban of grey squirrels in Italy (Inter-ministerial decree 
approved December $24^{\text {th }} 2012$ ) and trade restrictions at the European level (Commission Regulation n. 101/2012 of 6 February 2012 amending Council Regulation No 338/97 on the protection of species of wild fauna and flora by regulating trade therein) are a first step in reducing the risk, but their real effectiveness will have to be evaluated.

Finally, it must be stressed that the grey squirrel was deliberately introduced in Europe, as occurred in other parts of the world with many other vertebrates (Carrete and Tella 2008; Hulme et al. 2008; Bertolino 2009). The availability in pet shops of exotic species that may threaten native species if released, represents a high-risk pathway for new invasive introductions. Therefore the management of this risk should include the regulation of the pet trade with the ban of species that are considered or suspected to be potentially invasive.

Acknowledgements This paper is dedicated to Prof. Italo Currado (1936-2005) who first raised the attention on the risks posed by the presence of the grey squirrel in Italy. The surveys of the two squirrel species were funded by grants to the University of Turin from Provincia di Torino Servizio Tutela della Fauna e della Flora, Regione Piemonte Settore Pianificazione delle Aree Protette, Parco dei Laghi di Avigliana and Direzione Agricoltura Osservatorio faunistico regionale. We are grateful to Peter John Mazzoglio, the personnel of the Piedmont regional parks and all the other people that collaborated to the surveys. Constructive comments by two anonymous referees helped to improve the manuscript. This work was realized under the LIFE09 NAT/IT/000095 EC-

SQUARE Project. This is paper n. 1 of the EC-SQUARE project.

\section{References}

Bertolino S (2008) Introduction of the American grey squirrel (Sciurus carolinensis) in Europe: a case study in biological invasion. Curr Sci 95:903-906

Bertolino S (2009) Animal trade and non-indigenous species introduction: the world-wide spread of squirrels. Divers Distrib 15:701-708

Bertolino S, Genovesi P (2005) The application of the European strategy on invasive alien species: an example with introduced squirrels. Hystrix 16:59-69

Bertolino S, Lurz PWW (2013) Callosciurus squirrels: worldwide introductions, ecological impacts and recommendations to prevent the establishment of new invasive populations. Mammal Rev 43:22-33

Bertolino S, Lurz PWW, Sanderson R, Rushton S (2008) Predicting the Spread of the American Grey Squirrel (Sciurus carolinensis) in Europe: a Call for a Co-ordinated European Approach. Biol Cons 141:2564-2575

Bertolino S, Wauters L, Pizzul A, Molinari A, Lurz PWW, Tosi G (2009) A general approach of using hair-tubes to monitor the European red squirrel: a method applicable at regional and national scales. Mamm Bio 74:210-219

Bon M, Fasano D, Mezzavilla F. Zanetti M (2008) L'espansione dello scoiattolo comune, Sciurus vulgaris, in pianura veneta nell'ultimo decennio (1998-2007) (Rodentia: Sciuridae). Boll Museo civ Storia Nat Venezia 58 (suppl.):312-316

Cadi A, Joly P (2003) Competition for basking places between the endangered European pond turtle (Emys orbicularis galloitalica) and the introduced red-eared slider (Trachemys scripta elegans). Can J Zool 81:1392-1398

Carrete M, Tella JL (2008) Wild-bird trade and exotic invasions: a new link of conservation concern? Front Ecol Environ, 6:207-211 
Celada C, Bogliani G, Gariboldi A, Maracci A (1994) Occupancy of isolated woodlots by the red squirrel Scirus vulgaris in Italy. Biol Cons 69:177-183

Clavero M, Brotons L, Pons P, Sol D (2009) Prominent role of invasive species in avian biodiversity loss. Biol Cons 142:2043-2049

Collen B, Böhm M, Kemp R, Baillie JEM (2012) Spineless: status and trends of the world's invertebrates. Zoological Society of London, United Kingdom

Crooks JA (2005) Lag times and exotic species: The ecology and management of biological invasions in slow-motion. Ecoscience 12:316-329

Ehrenfeld JG (2010) Ecosystem consequences of biological invasions. Ann Rev Ecol Evol Syst 41:59-80

Ferreira RB, Callahan CM, Poessel SA, Beard KH (2012) Global assessment of establishment success for amphibian and reptile invaders. Wildl Res 39:637-640

Fitzgibbon CD (1993) The distribution of grey squirrels in farm woodland: the influence of wood area isolation and management. J Appl Ecol 30:736-742

Glen AS, Dickman CR (2008) Niche overlap between marsupial and eutherian carnivores: does competition threaten the endangered spotted-tailed quoll? J Appl Ecol 45:700-707

Gottero F, Ebone A, Terzuolo PG, Camerano P (2007) I boschi del Piemonte, conoscenze ed indirizzi gestionali. Blu edizioni, Regione Piemonte, Torino, Italy (in Italian).

Gurnell J, Kenward RE, Pepper H, Lurz PWW (2008) Grey Squirrel Sciurus carolinensis. In: Harris S, Yalden DW (eds.) Mammals of the British Isles: Handbook, 4th edition, 66-72. The Mammal Society, Southampton, UK

Gurnell J, Lurz PWW, Shirley MDF, Cartmel S, Garson PJ, Magris L, Steele J (2004) Monitoring tred squirrels Sciurus vulgaris and grey squirrels Sciurus carolinensis in Britain. Mammal Rev 34:51-74

Gurnell J, Pepper H (1993) A critical look at conserving the British red squirrel Sciurus vulgaris. Mammal Rev 23:125-136

Gurnell J, Wauters LA, Lurz PWW, Tosi G (2004) Alien species and interspecific competition: effects of introduced eastern grey squirrels on red squirrel population dynamics. J Anim Ecol 73:26-35

Hayes KR, Barry SC (2008) Are there any consistent predictors of invasion success? Biol Invas 10:483-506

Hulme PE, Bacher S, Kenis M, Klotz S, Kuhn I, Minchin D, Nentwig W, Olenin S, Panov V, Pergl J, Pysek P, Roques A, Sol D, Solarz W, Vila M (2008) Grasping at the routes of biological invasions: a framework for integrating pathways into policy. J Appl Ecol 45: 403-414

Jeschke JM, Strayer DL (2005) Invasion success of vertebrates in Europe and North America. PNAS 102:7198-7202

Kolar CS, Lodge DM (2001). Progress in invasion biology: predicting invaders. TREE 16:199-204

Lawton C, Cowan P, Bertolino S, Lurz PWW, Peters AR (2010) Consequences of introduction of non-indigenous species: two case studies, the grey squirrel in Europe and the brushtail possum in New Zealand. OIE Rev Scient Tech 29:113-122

Long JL (2003) Introduced Mammals of the World. Collingwood, Australia: CABI/CSIRO Publishing

Lurz PWW, Rushton SP, Wauters LA, Bertolino S, Currado I, Mazzoglio PJ, Shirley MDF (2001) Predicting grey squirrel expansion in North Italy: a spatially explicit modelling approach. Landsc Ecol 16:407-420

MacArthur R, Levins R (1967) The limiting similarity, convergence, and divergence of coexisting species. Am Nat 101:377-385

Marsico TD, Burt JW, Espeland EK, Gilchrist GW, Jamieson MA, Lindstrom L, Swope S, Roderick GK, Szucs M, Tsutsui ND (2010) Underutilized resources for studying the evolution 
of invasive species during their introduction, establishment and lag phases. Evol Appl 3:203219

Martinoli A, Bertolino S, Preatoni DG, Balduzzi A, Marsan A, Genovesi P, Tosi G, Wauters LA (2010). Headcount 2010: The multiplication of the grey squirrel populations introduced in Italy. Hystrix 21:127-136

Middleton AD (1932) The Grey Squirrel (Sciurus carolinensis) in the British Isles, 1930-1932. J Anim Ecol 1:166-167

Mayle B, Pepper H, Ferryman M (2003) Controlling grey squirrel damage to woodlands. Forestry Commission Practice Note 4:16

O'Teangana D, Reilly S, Montgomery WI, Rochford J (2000) Distribution and status of the red squirrel (Sciurus vulgaris) and grey squirrel (Sciurus carolinensis) in Ireland. Mammal Rev 30: 45-56.

Okubo A, Maini PK, Williamson MH, Murray JD (1989) On the spatial spread of the grey squirrel in Britain. Proc R Soc, Lond B 238:113-125

Peacock DE (2009) The grey squirrel Sciurus carolinensis in Adelaide, South Australia: its introduction and eradication. Victorian Nat 126:150-155

Reynolds JC (1985) Details of the geographic replacement of the Red Squirrel (Sciurus vulgaris) by the Grey Squirrel (Sciurus carolinensis) in Eastern England. J Anim Ecol 54:149-162

Rodrìguez A, Andrén H (1999) A comparison of Eurasian red squirrel distribution in different fragmented landscapes. J Appl Ecol 36:649-662

Rushton SP, Lurz PWW, Gurnell J, Nettleton P, Bruemmer C, Shirley MDF, Sainsbury AW (2006) Disease threats posed by alien species: the role of a poxvirus in the decline of the native red squirrel in Britain. Epidem Infect 134:521-533

Sainsbury AW, Nettleton P, Gilray J, Gurnell J (2000) Grey squirrels have high seroprevalence to a parapox virus associated with deaths in red squirrels. Animal Cons 3:229-233

Signorile AL, Evans J (2007) Damage caused by the American grey squirrel (Sciurus carolinensis) to agricultural crops, poplar plantations and semi-natural woodland in Piedmont, Italy. Forestry 80:89-98

Strayer DL (2012) Eight questions about invasions and ecosystem functioning. Ecol Letters 15:1199-1210

Tattoni C, Preatoni DG, Martinoli A, Bertolino S, Wauters LA (2005) Application of modelling techniques to manage a population of grey squirrels (Sciurus carolinensis) in Lombardy, northern Italy, and analysis of parameters estimates used in simulations Italian. Hystrix 16:99112

Tattoni C, Preatoni DG, Lurz PWW, Rushton SP, Tosi G, Martinoli A, Bertolino S, Wauters LA (2006) Modelling the expansion of grey squirrels (Sciurus carolinensis) in Lombardy, Northern Italy: implications for squirrel control. Biol Invasions 8:1605-1619

Tompkins DM, Sainsbury AW, Nettleton P, Buxton D, Gurnell J (2002) Parapoxvirus causes a deleterious disease in red squirrels associated with UK population declines. Proc R Soc, Lond B 269:529-533

Verbeylen G, De Bruyn L, Matthysen E (2003) Patch occupancy, population density and dynamics in a fragmented red squirrel Sciurus vulgaris population. Ecography 26:118-128

Vié JC, Hilton-Taylor C, Stuart SN (eds.) (2009) Wildlife in a Changing World - An Analysis of the 2008 IUCN Red List of Threatened Species. Gland, Switzerland: IUCN. 180 pp

Wauters LA, Gurnell J, Currado I, Mazzoglio PJ (1997a) Grey squirrel Sciurus carolinensis management in Italy - squirrel distribution in a highly fragmented landscape. Wildl Biol 3:117124 
Wauters LA, Currado I, Mazzoglio PJ, Gurnell J (1997b) Replacement of red squirrels by introduced grey squirrels in Italy: evidence from a distribution survey. In: Gurnell J, Lurz PWW (eds.) The Conservation of Red Squirrels Sciurus vulgaris L., 79-88. PTES, London, UK

Wauters LA, Gurnell J, Martinoli A (2002a) Interspecific competition between native Eurasian red squirrels and alien grey squirrels: does resource partitioning occur? Behav Ecol Sociobiol 52:332-341

Wauters LA, Tosi G, Gurnell J (2002b) Interspecific competition in tree squirrels: do introduced grey squirrels (Sciurus carolinensis) deplete tree seeds hoarded by red squirrels (S. vulgaris)?. Behav Ecol Sociobiol 51:360-367

Wauters LA, Verbeylen G, Preatoni D, Martinoli A, Matthysen E (2010) Dispersal and habitat cuing of Eurasian red squirrels in fragmented habitats. Pop Ecol 52: 527-536

Wauters LA, Preatoni D, Martinoli A, Verbeylen G, Matthysen E (2011) No sex bias in natal dispersal of Eurasian red squirrels. Mamm Bio 76:369-372

Williamson M (1996) Biological invasions. Chapman and Hall, Great Britain

Wittenberg R, Cock MJW (2001) Invasive alien species: a toolkit of best prevention and management practices. CABI Publishing, Wallingford, Oxon, UK

Zollner PA (2000) Comparing the landscape level perceptual abilities of forest sciurids in fragmented agricultural landscapes. Landsc Ecol 15:523-533 
Table 1. Spread dispersal $\left(\mathrm{V}_{\mathrm{min}}\right)$ and the two-dimensional diffusion coefficient (D) of the grey squirrel in Piedmont, Italy, between 1970 and 2010 compared with values in Ireland and England. $\begin{array}{cccccc}1970-1990 & 1990-2000 & 2000-2010 & 1970-2010 & \begin{array}{c}\text { Ireland } \\ \text { Oे Teangana et }\end{array} & \begin{array}{c}\text { England } \\ \text { Okubo et al }\end{array}\end{array}$ al. (2000) (1989)

\begin{tabular}{lllllcc}
\hline $\mathrm{V}_{\min }(\mathrm{km} /$ year $)$ & 0.33 & 0.65 & 0.56 & 0.37 & 1.94 & 7.66 \\
$\mathrm{D}\left(\mathrm{km}^{2} /\right.$ year $)$ & 0.03 & 0.13 & 0.10 & & 1.15 & 17.89 \\
\hline
\end{tabular}




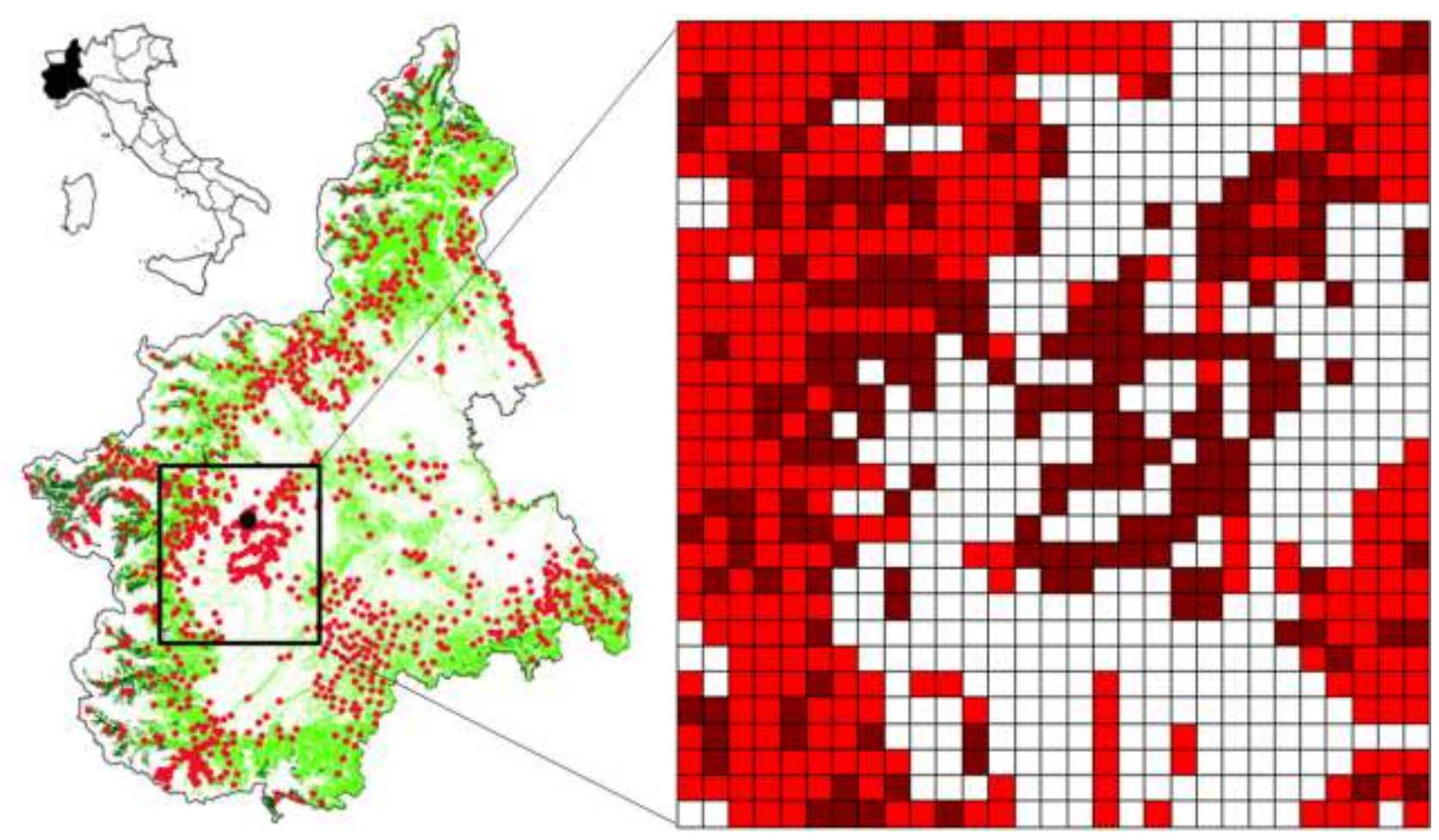

Fig.1 Distribution of the red squirrel (red dots) in Piedmont in the 1970s and study area of the grey squirrel spread (black square; the black dot indicate the Stupinigi forests); light green broadleaf forest, dark green coniferous forest. The study area is highlighted on the right with a grid $2 \times 2 \mathrm{~km}^{2}$; white squares: open areas not suitable for red squirrels; light red squares: forested area suitable for red squirrels; dark red squares: presence of the red squirrel recorded. Dark and light red squares represent the probable distribution of the red squirrel before grey squirrel invasion. 


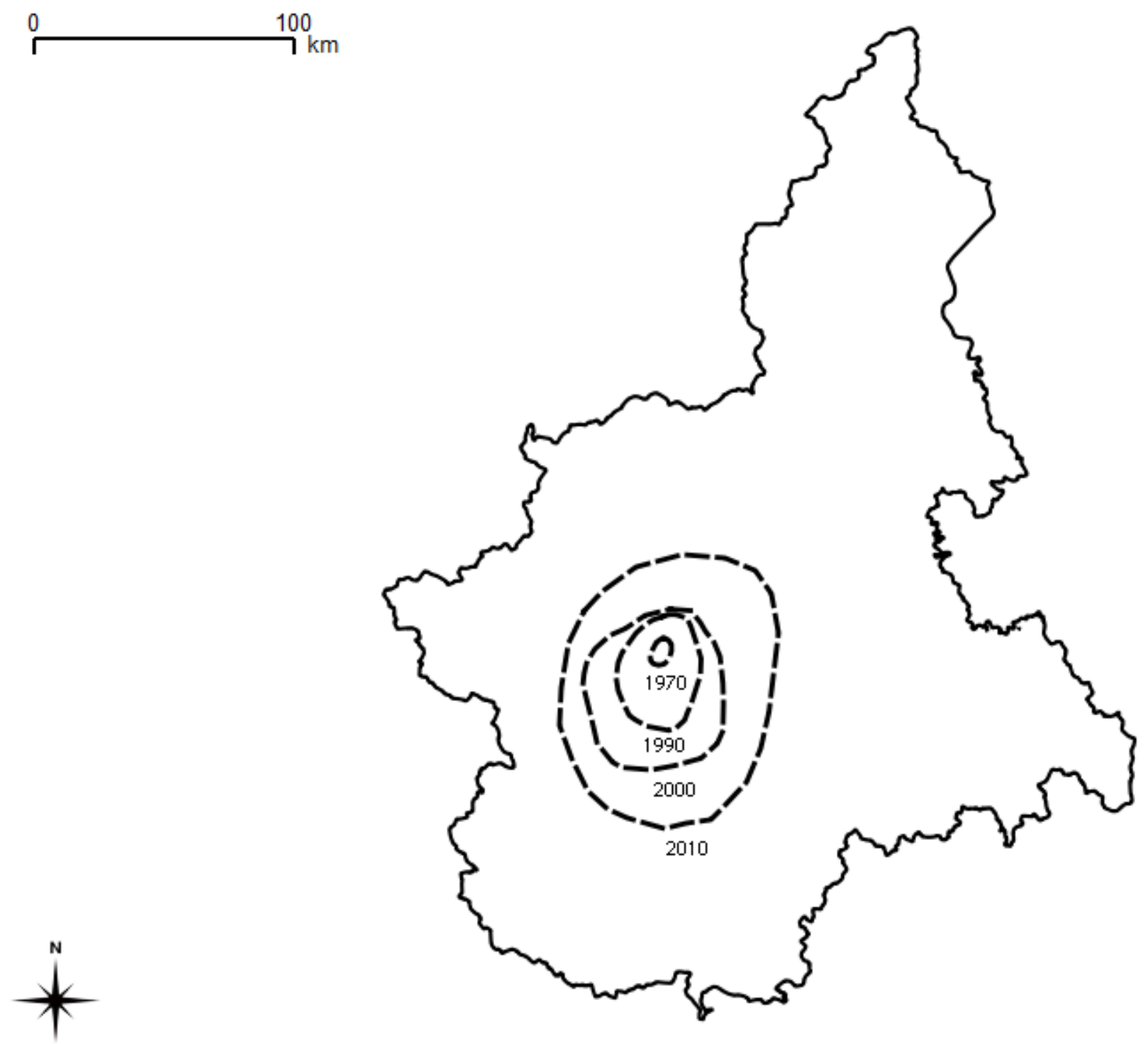

Fig. 2 Grey squirrel spread in the periods 1970-2010. The dotted lines indicate the ranges in years 1970, 1990, 2000, 2010). . 


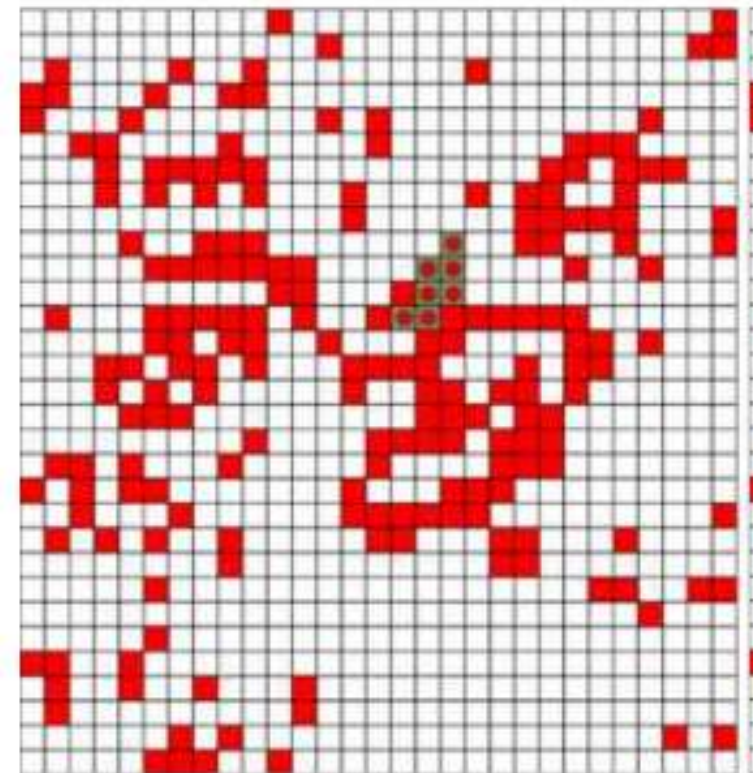

1970

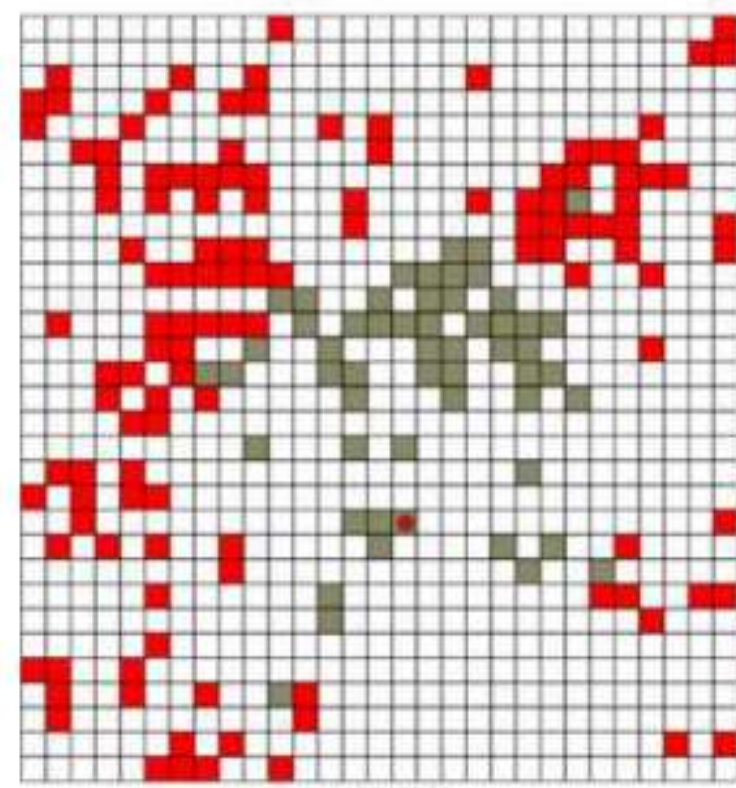

2000

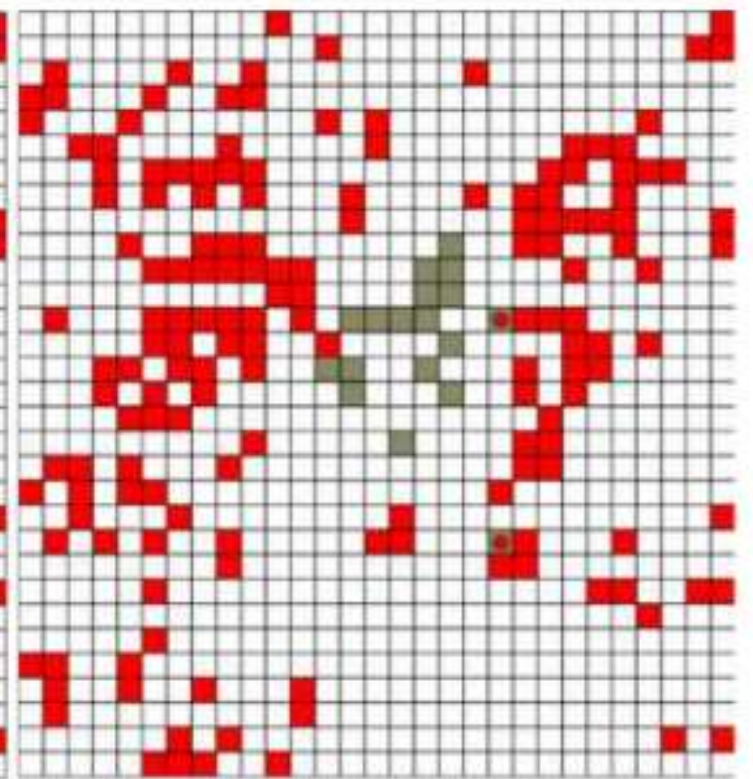

1990

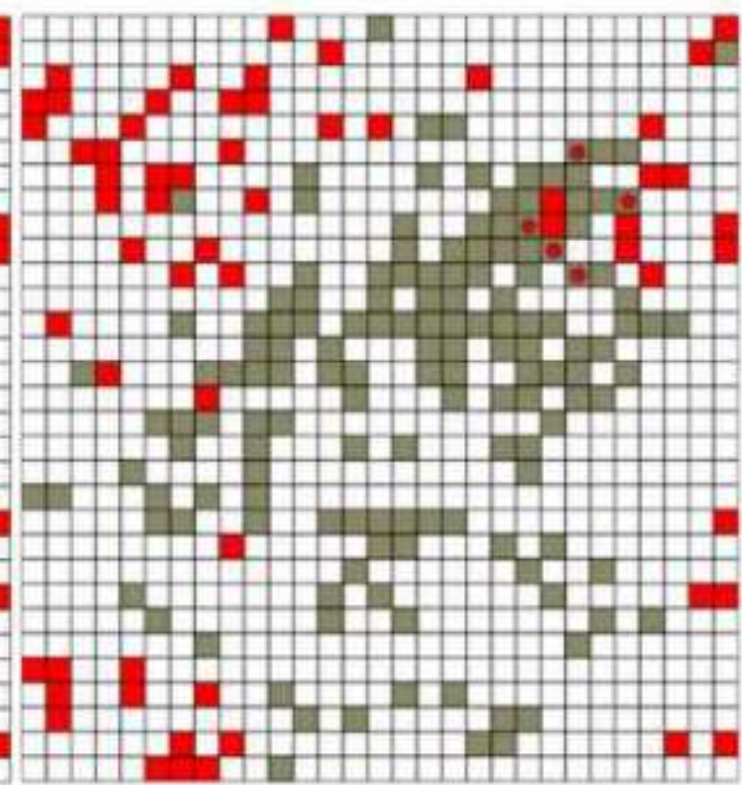

2010

Fig. 3 Distribution maps of red (red square) and grey (grey square) squirrels in Piedmont, Italy, from 1970 to 2010 . Grey square with red dots indicate areas with both species. The grid is $2 \times 2$ square $\mathrm{km}$. 


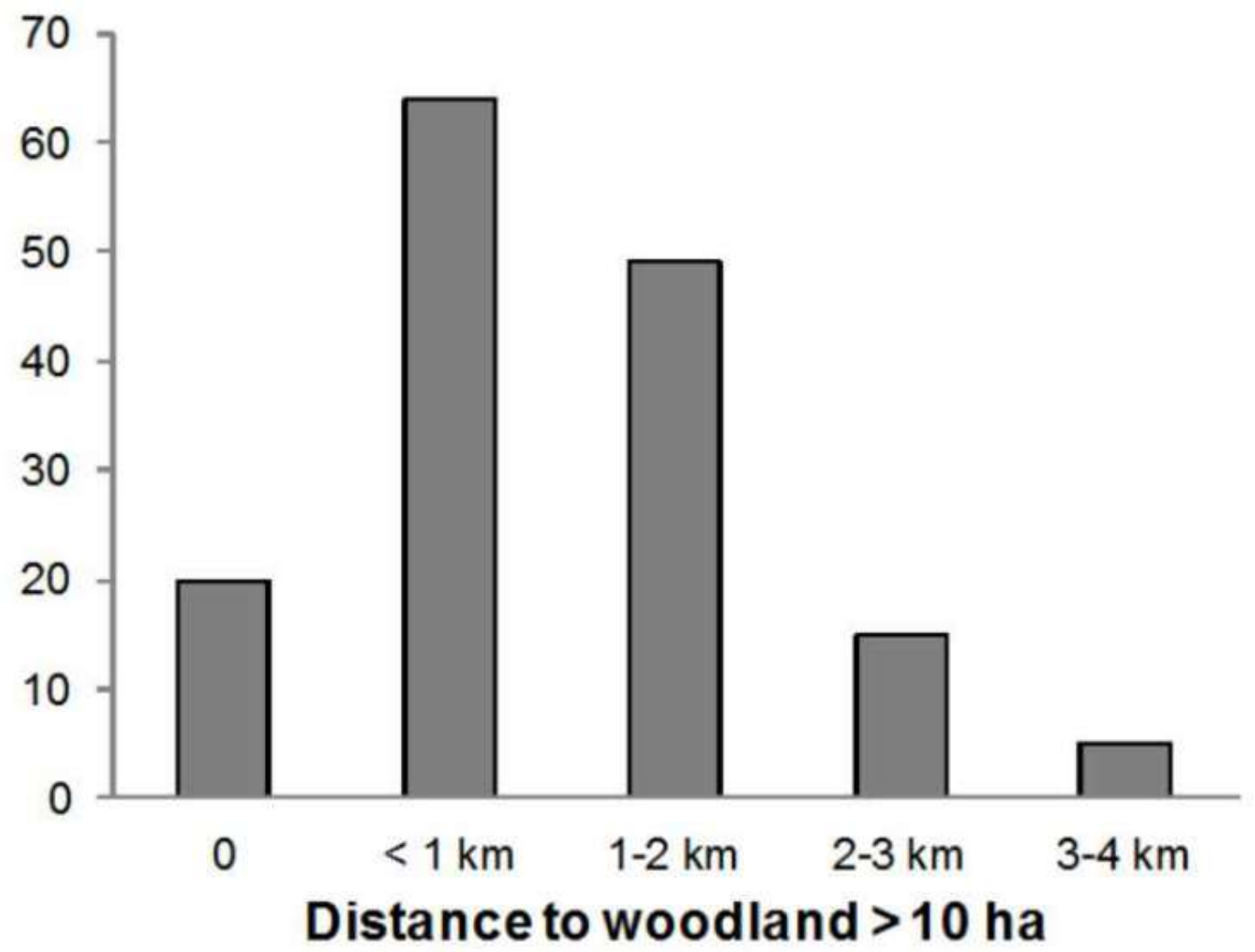

Fig. 4 Distance to woodlands $>10$ ha of forest patches were red squirrels went extinct after the arrival of the grey squirrel.

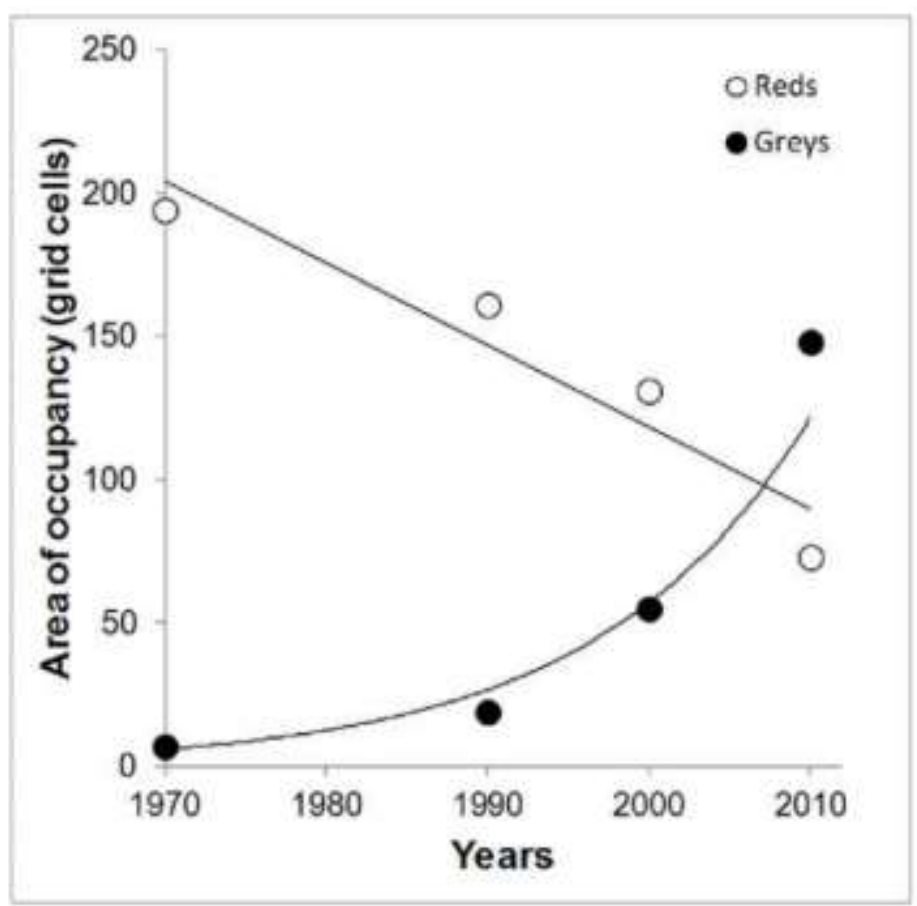

Fig. 5 Area of occupancy of grey and red squirrels from 1970 to 2010 and fitted regression curves. 


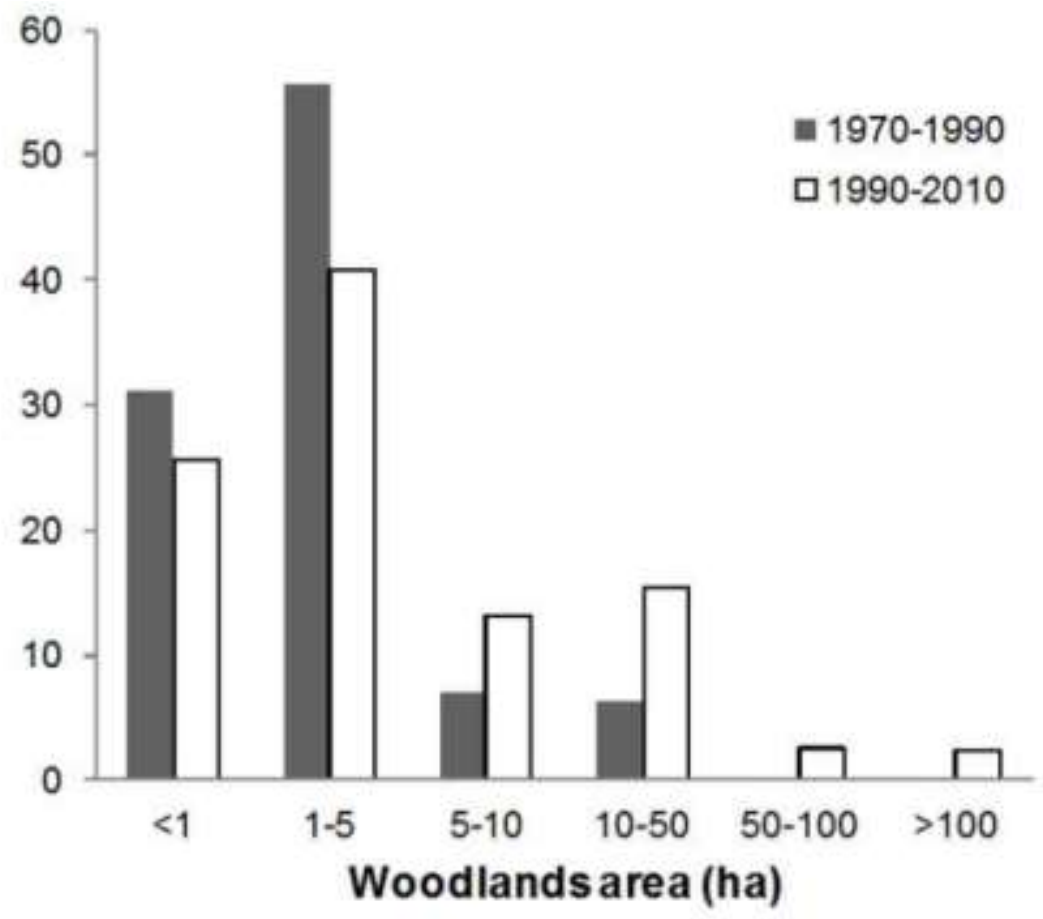

Fig. 6 Area of woodlands where grey squirrels were recorded in the period 1970-1990 and in the period 1990-2010. 